\title{
Pengaruh First Pshycological Aid Dalam Meningkatkan Regulasi Emosi Dan Coping Stress Anak Panti Asuhan Di Kota Kudus
}

\author{
Dwi Astuti \\ dwi.astuti@umk.ac.id
}

Fajar Kawuryan

Fakultas Psikologi, Universitas Muria Kudus, Indonesia

\begin{abstract}
Preeliminary research in severals orphanage in Kudus showed that $37 \%$ of students experienced mild stress, $32 \%$ of students experienced moderate stress, $27 \%$ of students experienced severe stress, and $4 \%$ of students experience very heavy stress. Based on the stress level classification, in the same study it was identified that 13\% of students had indigestion, $47 \%$ of students had headaches, $3 \%$ of students had skin disorders, $8 \%$ of students had high blood pressure, $11 \%$ of students had respiratory problems, and $18 \%$ of students experience other disorders, including insomnia (unable to sleep), difficulty concentrating, easily anxious and confused, body weakness, laziness, heart palpitations, becoming more sensitive and emotional, and inferior to the opposite sex due to stress experienced. Based on interviews with Darussalam Orphanage caregivers, it was found that the symptoms of stress were also experienced by many children at the Darussalam Orphanage, which disrupted their daily activities at the cottage and at school. Most are caused by broken home family conditions, thereby neglecting the psychological, social and economic needs of children. The process by which a person copes with stress is called coping (the ability to deal with problems). The author strives for a way to improve the ability to regulate emotions and coping with stress in Darussalam orphanage children by using First Psychological Aid training. The results of this activity, have shown increased ability to regulate emotions and coping with stress. Changes were also seen in the behavior of Darussalamah orphanage children who were getting better during and after training.
\end{abstract}

Keywords: coping stress; emotion regulation; first psychologycal aids.

\begin{abstract}
Abstrak
Penelitian awal terkait kondisi remaja di beberapa panti asuhan kota Kudus menunjukkan bahwa $37 \%$ remaja mengalami stres ringan, 32\% mengalami stres dalam tingkat sedang, $27 \%$ mengalami stres dalam tingkat berat, dan $4 \%$ mmengalami stres sangat berat. Berdasarkan klasifikasi tingkatan stres tersebut, dalam penelitian yang sama teridentifikasi bahwa $13 \%$ remaja mengalami gangguan pencernaan, $47 \%$ mengalami sakit kepala, 3\% mengalami gangguan kulit, $8 \%$ mengalami tekanan darah tinggi, 11\% mengalami gangguan pernafasan, dan 18\% mengalami gangguan yang lain, meliputi insomnia (tidak bisa tidur), sulit berkonsentrasi, mudah cemas dan bingung, badan lemas, malas, jantung berdebar-debar, menjadi lebih sensitif dan emosional, serta minder dengan lawan jenis disebabkan stres yang dialami. Hal ini tentunya mengganggu kegiatan sehari-hari mereka di pondok dan di sekolah. Kebanyakan disebabkan karena kondisi keluarga yang broken home, sehingga menelantarkan kebutuhan psikologis, sosial, dan ekonomi anak. Proses yang dilakukan seseorang untuk mengatasi stres dinamakan coping (kemampuan mengatasi masalah). Peneliti mengupayakan salah satu cara meningkatkan kemampuan regulasi emosi dan coping stress pada remaja panti asuhan dengan menggunakan pelatihan First Psychological Aid. Hasil dari kegiatan ini, telah menunjukkan peningkatan kemampuan regulasi emosi dan coping stress. Perubahan juga terlihat pada perilaku remaja panti asuhan yang semakin baik selama dan sesudah pelatihan.
\end{abstract}


Kata kunci : coping stress; first psychologycal aids, regulasi emosi.

Psikoislamika: Jurnal Psikologi dan Psikologi Islam (JPPI) Volume 16. Nomor 1. Tahun 2019. Copyright (C) 2019. Pusat Penelitian dan Layanan Psikologi.

\section{PENDAHULUAN}

Stres dipahami tidak hanya menjadi fenomena universal tetapi juga pengalaman universal, dan cara orang merespons dan mengatasi stres berbeda (Grover, dkk, 2015). Namun penelitian telah menunjukkan bahwa berbagai tingkat stres yang dialami oleh siswa dapat mempengaruhi fungsi dan kinerja mereka secara keseluruhan. Sementara stres dianggap sebagai bagian penting dari kehidupan menuju pengembangan pribadi, tidak semua individu mampu mengatasinya secara memadai ( Kasayira,dkk, 2007; Shaheen F \& Alam, 2010; Carver CS, Scheier MF \& Werintraub, 1989) .

Stres diartikan sebagai suatu keadaan psikologis dimana seseorang merasa tertekan karena persoalan yang dihadapi. Persoalan yang berkepanjangan tanpa ada suatu penyelesaian yang jelas dapat menjadi tekanan psikologis dan tekanan ini dapat mengganggu fungsi psikologis seseorang secara umum. Taylor (Durand dan Barlow, 2006) mendefinisikan stres sebagai bentuk dari pengalaman emosional negatif yang disertai perubahan reaksi biokimiawi, fisiologis, kognitif dan perilaku yang bertujuan untuk mengubah atau menyesuaikan diri terhadap situasi yang menyebabkan stres. Beberapa orang tidak menyadari ketika dirinya sedang mengalami stres. Individu hanya merasa pusing, cepat telah, dan staminanya menurun. Walapun terkesan tidak penting sehingga sering dianggap sepele, namun sebenarnya juga membehayakan. Kondisi tersebut apabila tidak segera dilakukan mekanisme penyesuaian diri yang tepat untuk menyelesaikan stresor (penyebab stres), maka stres yang berkepanjangan dapat menjadi 'bom waktu' yang suatu saat dapat membuat individu mengalami gangguan mental yang lebih berat. Hal ini sesuai dengan yang dikemukakan Daradjat (2006) bahwa kecemasan yang berat dan berlangsung lama akan menurunkan kemampuan dan efisiensi seseorang dalam menjalankan fungsi-fungsi hidupnya dan pada akhirnya dapat menimbulkan berbagai macam gangguan jiwa.

Penelitian yang dilakukan Kawuryan \& Astuti (2015) tentang Identifikasi Stresor Mahasiswa sebanyak 120 responden dari enam fakultas yang berbeda, menunjukkan bahwa $37 \%$ mahasiswa mengalami stres ringan, $32 \%$ mahasiswa mengalami stres 
dalam tingkat sedang, $27 \%$ mahasiswa mengalami stres dalam tingkat berat, selain itu 4\% mahasiswa mengalami stres sangat berat. Berdasarkan klasifikasi tingkatan stres tersebut, dalam penelitian yang sama teridentifikasi bahwa $13 \%$ mahasiswa mengalami gangguan pencernaan, 47\% mahasiswa mengalami sakit kepala, 3\% mahasiswa mengalami gangguan kulit, 8\% mahasiswa mengalami tekanan darah tinggi, $11 \%$ mahasiswa mengalami gangguan pernafasan, dan $18 \%$ mahasiswa mengalami gangguan yang lain, meliputi insomnia (tidak bisa tidur), sulit berkonsentrasi, mudah cemas dan bingung, badan lemas, malas, jantung berdebar-debar, menjadi lebih sensitif dan emosional, serta minder dengan lawan jenis disebabkan stres yang dialami. Sebagian besar dari mereka kemudian bermasalah dalam proses perkuliahannya, menjadi jarang hadir bahkan ada yang sama sekali tidak hadir dalam perkuliahan tanpa keterangan yang jelas. Hal tersebut sangat berdampak negative bagi kehidupan secara umum.

Hal senada juga terjadi pada penghuni salah satu Panti Asuhan di Kabupaten Kudus. Hasil preliminary research, peneliti mendapatkan fakta bahwa dari hari ke hari makin banyak anak panti yang mengalami gangguan psikologis. Hal ini dibuktikan dengan semakin banyak anak panti yang melakukan tindakan kurang kooperatif, misalnya diam ketika ditanya, menutup komunikasi dengan teman-teman sesama penghuni panti dan pengasuh, berperilaku agresif pada sesama anak panti, tidak bersemangat bersekolah, bahkan ada yang mengalami gangguan kesehatan, seperti sering pusing dan gangguan pencernaan data ini berdasarkan wawancara baik dari pengelaola panti, maupun dari remaja panti asuhan sendiri. Anak anak panti juga menjadi kotrban bullying dari teman - teman disekolahnya. Mereka merasa berbeda dan serin g dianggap rendah, sehingga sering di remehkan dan mendapatkan perlakukan yang kurang layak.

Sering mendapatkan perlakukan tersebut menimbulkan perasaan yang sangat tidak nyaman. Namun mereka tidak mampu berbuat banyak dan hanya cenderung diam. Tanpa mereka sadari mulai muncul kecenderungan memendam masalah yang mengakibatkan kondisi emosi tidak stabil yang dapat mempengaruhi baik psikis, cara berfikir dan berprilaku (Beck, 2011). Emosi dan kondisi fisiologis yang ditimbulkan oleh stres sangat tidak nyaman, sehingga memotivasi individu untuk melakukan sesuatu guna menghilangkannya. Proses yang dilakukan seseorang untuk mengatasi stres dinamakan coping (kemampuan mengatasi 
masalah). Dibutuhkan regulasi emosi dan kemampuan coping stress untuk mengatasi stres yang dialami mahasiswa agar tidak berimbas pada kesehatan fisik, psikis, dan sosialnya (Lazarus, 1986).

Tujuan dari penelitian ini adalah untuk melihat apakah penerapan First Psychological Aid dapat meningkatkan regulasi emosi dan Coping Stress pada anak Panti Asuhan.

\section{Coping Stress}

Copping didefinisikan sebagai proses yang terus-menerus mengubah upaya kognitif dan perilaku untuk mengelola tuntutan eksternal atau internal tertentu yang dinilai sebagai pajak atau melebihi sumber daya orang. Strategi koping dianggap sebagai upaya khusus tersebut, baik perilaku dan psikologis, yang digunakan seseorang untuk menguasai, mengurangi atau meminimalkan dan mentolerir peristiwa yang menimbulkan stress (Sreeramareddy, 2007).

Sejumlah penelitian yang meneliti stres dan koping telah dilakukan sejak kerangka teori pertama kali diperkenalkan dan disajikan ( Shaheen F \& Alam, 2010; Kumar S. \& Jejurkar K, 2005; Folkman, 2013) . Lazarus dan Folkman (Folkman, 2013) menggambarkan delapan jenis strategi koping luas yang dapat digunakan individu dalam situasi yang penuh tekanan. Kedelapan tipe koping ini selanjutnya diklasifikasikan ke dalam dua kategori besar, yaitu. strategi koping yang berfokus pada masalah dan emosi. Strategi koping yang berfokus pada masalah termasuk mencari dukungan sosial dan koping yang berfokus pada masalah. Strategi koping yang berfokus pada emosi meliputi fokus pada pikiran positif, menyalahkan diri sendiri, angan-angan, menjaga diri, melepaskan dan mengurangi ketegangan

Kedua jenis strategi koping digunakan oleh individu dalam peristiwa-peristiwa yang penuh tekanan dan akan dibahas secara singkat. Coping yang berfokus pada masalah adalah ketika individu berinteraksi dengan lingkungan melalui tindakan langsung, pemecahan masalah dan pengambilan keputusan aktif (Folkman, 2013). Holland (Folkman, 2013) menambahkan bahwa tindakan langsung melibatkan mengubah situasi / peristiwa atau mengubah diri untuk menghilangkan sumber stres. Secara keseluruhan, strategi koping yang berfokus pada masalah ditujukan untuk mengurangi tuntutan situasi atau stresor dengan memperluas sumber daya untuk menangani stressor (Folkman, 2013) dan sering digunakan ketika orang tersebut percaya bahwa permintaan / stresor dapat diubah (Folkman, 2013). Strategi yang berfokus pada masalah dan metode berpikir positif untuk 
mengatasi dianggap strategi mengatasi yang adaptif yang mengurangi stress (Shaheen F \& Alam, 2010). Strategi koping yang berfokus pada masalah (Folkman, 2013), meliputi:

1. Mengidentifikasi, merencanakan bagaimana menghadapi stresor dan merencanakan upaya koping seseorang. Individu terlibat dalam perilaku pemecahan masalah.

2. Mencari dukungan sosial.

3. Mengambil tindakan tegas, menganalisis situasi untuk sampai pada solusi dan mengambil tindakan langsung untuk memperbaiki masalah.

4. Berusaha mengubah lingkungan atau dengan memfokuskan pada sesuatu yang tidak terkait dengan stressor untuk mengubah pikiran mereka atau menghindari memikirkan situasi atau stressor.

Studi sebelumnya, menyoroti bahwa strategi koping yang digunakan baik yang berfokus pada masalah seperti penyelesaian masalah, perencanaan, penerimaan, koping aktif, mengatur waktu mereka, mencari informasi dan olahraga dan kegiatan rekreasi atau mereka mempekerjakan strategi yang berfokus pada emosi seperti strategi pengurangan ketegangan seperti berolahraga, diet seimbang, cukup tidur, dan terlibat dalam strategi kegiatan rekreasi yang konstruktif (Shaheen F \& Alam, 2010; Shankar PR, 2007; Folkman, 2013). Strategi koping yang berfokus pada emosi adalah semua upaya yang diarahkan untuk mengubah respons emosional terhadap stress (Robotham, 2008). Upaya diarahkan untuk meminimalkan efek negatif dari stresor, oleh karena itu individu merasa lebih baik tetapi masalahnya tidak terpecahkan. Dengan demikian strategi koping yang berfokus pada emosi ditujukan untuk mengurangi dampak dari stresor yang dirasakan jika stresor tidak dapat diubah atau dihindari, atau jika individu menganggap stresor itu sangat mengancam, tidak dapat diubah, dan tidak terkendali.

Strategi-strategi coping yang berfokus pada emosi ( Folkman, 2013) meliputi:

1. Penghindaran, kehilangan harapan, minimalisasi, menjauhkan, perhatian selektif dan perbandingan positif,

2. Penilaian kembali positif dan rasionalisasi,

3. Merokok, penyalahgunaan obatobatan, tidur dan makan,

4. Angan-angan dan menyalahkan diri sendiri,

5. Penolakan, penarikan sosial dan penghindaran. 
Strategi yang berfokus pada emosi seperti penghindaran dan pemikiran negatif sebagai respons terhadap stresor dianggap sebagai metode penanganan yang maladaptive (Shaheen F \& Alam, 2010). Ketika mengatasi stres, fokus pada emosi dapat berdampak negatif pada penyesuaian seseorang terhadap situasinya5 dan gaya menghindari koping dapat menyebabkan tekanan psikologis (Shaheen F \& Alam , 2010; Carver, 1989). Bergantung pada situasi, respons koping tertentu mungkin efektif untuk beberapa individu sementara itu merugikan orang lain5. Penelitian telah menunjukkan bahwa ada hubungan antara coping yang berfokus pada emosi dan gejala seperti depresi dan kecemasan (Kausar, 2010; Dawson,2009). Meskipun metode koping ini dapat mengurangi tingkat stres seseorang, metode ini meningkatkan kesehatan jangka panjang (Shaheen F \& Alam, 2010). Selain itu, konsekuensi dari penanganan maladaptif dapat menyebabkan penurunan harga diri, peningkatan konsumsi alkohol dan merokok, berkurangnya fungsi sistem kekebalan tubuh (Mosley, 1994), peningkatan kecenderungan bunuh diri, kinerja akademis yang buruk dan putus sekolah (Sarid,dkk, 2004). Sebuah studi yang dilakukan di sebuah sekolah kedokteran di Pakistan menunjukkan bahwa sebagian besar siswa mengalami gejala suasana hati yang rendah, ketidakmampuan untuk berkonsentrasi, temperamen pendek, perubahan tidur.

Coping stress membutuhkan latihan. Dalam proses coping stress dibutuhkan kemampuan dalam mengelola emosi maupun mengelola masalah yang dihadapinya (Lazarus dan Folkman, 1986). Masa remaja masih membutuhkan bimbingan dan pengawasan dari figure orang yang lebih dewasa, karena mereka masih sangat labil, dan proses berfikir belum matang karena belum memiliki banyak pengalaman. Sosok orang lebih dewasa dapat menjadi sosok panuitan atau seseorang untuk memberikan wacana, pandangan yang lebih luas (Gunarsa, 2008).

\section{Regulasi Emosi}

Daniel Goleman (2002) mengatakan bahwa emosi merujuk pada suatu perasaan dan pikiran yang khas, suatu keadaan biologis dan psikologis dan serangkaian kecenderungan untuk bertindak. Emosi merupakan reaksi terhadap rangsangan dari luar dan dalam diri individu, sebagai contoh emosi gembira mendorong perubahan suasana hati seseorang, sehingga secara fisiologi terlihat tertawa, emosi sedih mendorong seseorang berperilaku menangis.

Emosi cenderung terjadi dalam kaitannya dengan perilaku yang mengarah 
(approach) atau menyingkir (avoidance) terhadap sesuatu. Perilaku tersebut pada umumnya disertai adanya ekspresi kejasmanian sehingga orang lain dapat mengetahui bahwa seseorang sedang mengalami emosi. Jika seseorang mengalami ketakutan mukanya menjadi pucat, jantungnya berdebar-debar, jadi adanya perubahan-perubahan kejasmanian sebagai rangkaian dari emosi yang dialami oleh individu yang bersangkutan (Walgito, 1994).

Emosi dapat dilihat sebagai kondisi mental yang muncul secara spontan daripada melalui upaya sadar dan yang sering disertai dengan perubahan fisiologis yang berbeda. Pengaruhnya dapat didefinisikan sebagai pengalaman sadar dari emosi semacam itu. Ekman (2003) menyarankan bahwa emotions emosi kita sering kali merupakan panduan terbaik kita. Mengarahkan kita untuk melakukan dan berkata apa yang tepat untuk situasi ini '(hlm. 52), tetapi itu tidak selalu demikian bagi siapa pun, dalam beberapa hal emosi dapat membanjiri individu (seperti kemarahan atau ketakutan). Karena itu, emosi jelas dapat memiliki efek besar pada cara seseorang berpikir dan merasakan, dalam arti adanya multifaset dan melibatkan perubahan multisistem. Gross dan Thompson (2007) mencatat bahwa keadaan emosional dapat memiliki hubungan langsung dengan tujuan individu, agar memulai perubahan perilaku, melalui fungsi otonom atau fisiologis lainnya perubahan.

Ekman (1999) telah memperluas daftar emosi dasar ini dengan memasukkan a rentang emosi positif dan negatif (tidak semua yang dikodekan dalam otot wajah), yaitu hiburan, penghinaan, kepuasan, rasa malu, kegembiraan, rasa bersalah, kebanggaan akan prestasi, kelegaan, kepuasan, kesenangan indrawi, dan rasa malu. Emosi dapat dialami sebagai positif atau negatif, cepat berlalu atau lebih lama, dan pada berbagai tingkat intensitas, dari yang sangat lemah hingga yang sangat kuat (yang bisa terkadang membanjiri individu dalam hal kesedihan atau ketakutan).

Regulasi emosi adalah cara individu mengolah emosi yang mereka miliki, kapan mereka merasakannya, dan bagaimana mereka mengalami atau mengekspresikan emosi tersebut (Gross, 1999). Menurut Gross \&John (2003), regulasi emosi adalah usaha individu untuk mempengaruhi emosi yang mereka alami, dan bagaimana emosi ini dihayati dan diekspresikan.

Regulasi emosi juga dapat diartikan sebagai kemampuan untuk mengevaluasi dan mengubah reaksi-reaksi emosional untuk bertingkah laku tertentu yang sesuai dengan situasi yang sedang terjadi (Thompson, 2001). 
Rothbart dan Sheese (2007) menyatakan bahwa regulasi emosi merupakan perubahan dari reaksi emosi, yang meliputi inhibisi, aktivasi, atau perubahan bertingkat. Rothbart dan Sheese juga menyatakan bahwa regulasi emosi meliputi strategi yang diterapkan melalui usaha pengendalian dan perubahan pengaruh terhadap emosi.

Menurut Gross (1998) bahwa terdapat pengaruh regulasi, antara lain :Coping, Mood Regulation (pengaturan mood), Defenses (pertahanan), danEmotion Regulation (Regulasi Emosi). Dalam regulasi emosi terdiri atas bagian-bagianregulasi emosi, antara lain: kepribadian, klinis, kesehatan, biologi, kognitif,perkembangan, dan sosial.

Kualitas-kualitas emosi ini membentuk apa yang disebut model modal emosi (Gross, 1998a), yang terdiri dari empat langkah atau peristiwa dalam generasi respons emosional:

1. Situasi,

2. Perhatian,

3. Penilaian,

4. Rrespons.

Menurut model, secara psikologis situasi yang relevan (eksternal atau internal) menarik perhatian kami dan memunculkan proses penilaian situasi. Penilaian ini dapat terjadi di sejumlah dimensi (Ellsworth \&
Scherer, 2003). Dimensi ini mencakup penilaian sebagai berikut:

1. Kebaruan situasi, yaitu sejauh mana perhatian tertarik atau berorientasi pada perubahan lingkungan;

2. Kesenangan atau valensi dari situasi, yang dapat mengarah pada perilaku pendekatan atau penghindaran;

3. Relevansi motivasi situasi dengan individu. Setelah penilaian situasi, respons emosional dapat dihasilkan.

Respons emosional ini dapat memberi umpan balik kepada, dan menyebabkan perubahan, pada situasi aslinya. Respons emosional kita yang marah telah menyebabkan perubahan dalam situasi, dan kita sekarang harus menanggapi situasi baru, situasi di mana tetangga kami (semoga) mengurangi volume musik mereka. Ini baru situasi mungkin memerlukan respons emosional yang berbeda terhadap kemarahan, yang mungkin lagi berpengaruh pada situasi. Karena itu, emosi terus-menerus melunak situasi di mana kita menemukan diri kita sendiri, menyebabkan kita menilai kembali dan merespons situasi yang berkembang (Gross \& Thompson, 2007).

Gross (1998b) mengemukakan bahwa strategi yang berbeda untuk regulasi emosional dapat berlangsung di lima titik di sepanjang rantai peristiwa yang membentuk 
model modal emosi. Dari lima strategi ini, empat mewakili strategi yang berfokus pada anteseden, pemilihan situasi yang disebut, modifikasi situasi, penyebaran perhatian, dan perubahan kognitif, dan satu strategi yang berfokus pada respons telah dicatat, yaitu modulasi respons. Seleksi situasi melibatkan penghindaran atau pencarian situasi, berdasarkan masa lalu pengalaman atau pemikiran, yang mengarah pada generasi respon emosional yang diberikan. Modifikasi situasi mengacu pada upaya untuk mengubah situasi fisik dan eksternal yang diberikan sedemikian rupa sehingga hasilnya menjadi lebih, atau kurang, diinginkan.

Emosi juga bisa diatur tanpa perlu mengubah atau memodifikasi situasi fisik. Dalam keadaan seperti itu, seseorang dapat mengatur emosi seseorang melalui konsentrasi atau gangguan, keduanya yang merupakan sarana pengalihan perhatian. Konsentrasi melibatkan mengarahkan perhatian terhadap fitur emosional dari situasi, gangguan melibatkan pergeseran perhatian menjauh dari, atau menuju, aspek yang berbeda situasi (Gross \& Thompson, 2007). Pengalihan perhatian sebagai sarana regulasi emosional juga dapat mencakup upaya fisik untuk menarik perhatian (untuk misalnya, menarik perhatian visual dengan menutupi mata kita), atau upaya orang lain orang untuk mengalihkan perhatian kita (misalnya, memegang mainan yang suka diemong di depan sebuah bayi duduk dengan gugup di kursi dokter gigi). Perubahan kognitif, strategi terakhir adalah berfokus pada anteseden, mengacu pada kemampuan untuk mengubah cara kita menilai situasi emosional. Ochsner dan Gross (2007), penilaian kembali situasi emosional, misalnya sebagai ancaman atau penghargaan, mewakili salah satu bentuk perubahan kognitif. Melalui penggunaan penilaian ulang, respons emosional untuk situasi yang sama dapat bervariasi sebagai produk keadaan, tujuan, dan motivasi, sebuah proses yang bergantung pada berfungsinya proses kognitif tingkat tinggi (Ochsner \& Gross, 2005). Penggunaan modulasi respons dapat digunakan untuk memodulasi atau mengubah respons kita mengikuti generasi respons emosional.

Gross dan Thompson (2007) mengemukakan bahwa modulasi respons melibatkan pengaruh langsung pada fisiologi, pengalaman, atau tingkah laku. Represi mewakili satu bentuk umum dari modulasi respons, di mana perilaku ekspresif secara emosional dihambat ketika dalam keadaan gairah emosional (Gross \& Levenson, 1993). Selain itu, represi telah dikaitkan dengan efek pada ekspresif perilaku dan fisiologi sambil menghambat keadaan emosi negatif dan 
positif (Gross, 1998b; Gross \& Levenson, 1997). Menurut Davidson et al. (2002), regulasi emosional yang terganggu dapat mewakili komponen penting dari gangguan emosi. Campbell-Sills dan Barlow (2007) mengemukakan bahwa regulasi emosi yang tidak efektif dan maladaptif, khususnya kecenderungan represi dan regulasi emosi negatif, mungkin relevan dengan kecemasan dan gangguan mood.

Regulasi emosi adalah kemampuan untuk mengevaluasi dan mengubah reaksireaksi emosional untuk bertingkah laku tertentu yang sesuai dengan situasi yang sedang terjadi (Thompson, 2001), sedangkan Radley (Rahmayanti, 2009) mengungkapkan bahwa coping stress diartikan sebagai penyesuaian secara kognitif dan perilaku menuju keadaan yang lebih baik,mengurangi, dan bertoleransi dengan tuntutan-tuntutan yang mengakibatkan stres. Lazarus dan Folkman (1988) mengungkapkan bahwa setiap individu melakukan cara coping yang berbeda dalam menghadapi situasi yang menekan dari lingkungan, meliputi kognitif (pola pikir) dan perilaku (tindakan).

\section{First Psychologycal Aid}

First Psychologycal Aid (FPA) merupakan pertolongan pertama yang dapat dilakukan dalam penanganan individu yang mengalami gejolak psikis. FPA adalah sebuah pendekatan yang dapat dipelajari oleh para profesional dan non-profesional yang berada dalam posisi untuk membantu orang-orang yang terkena dampak peristiwa yang sangat menyedihkan. Mereka termasuk staf atau relawan dari organisasi bantuan bencana (di sektor kesehatan dan non-kesehatan), tenaga kesehatan, guru, masyarakat, dan pejabat pemerintah daerah. Dalam hal ini, FPA yang dilakukan adalah pertolongan pertama pada mahasiswa yang mengalami stres dengan melatih kemampuan regulasi emosi dan coping stresnya.

Prinsip dan teknik Psychological First Aid memenuhi empat standar dasar, yaitu :

a. Konsisten dengan bukti penelitian tentang trauma risiko dan ketahanan berikut

b. Berlaku dan praktis dalam pengaturan bidang

c. Sesuai untuk tingkat perkembangan seluruh jangka hidup

d. Budaya informasi dan disampaikan dalam cara yang fleksibel

Psychological First Aid tidak berasumsi bahwa semua korban akan mengembangkan parah mental yang masalah kesehatan atau kesulitan jangka panjang dalam pemulihan. Sebaliknya, itu didasarkan pada memahami bahwa korban bencana dan 
lain-lain dipengaruhi oleh peristiwa tersebut akan mengalami berbagai reaksi awal (misalnya, fisik, psikologis, perilaku, rohani). Beberapa reaksi ini akan menyebabkan cukup kesulitan untuk mengganggu koping adaptif, dan pemulihan dapat dibantu dengan dukungan dari responden bencana penuh kasih dan peduli.

Strategi intervensi Pertolongan

Pertama psikologis dimaksudkan untuk digunakan dengan anak-anak, remaja, orang tua, pengasuh, keluarga, dan orang dewasa terkena bencana atau terorisme. First Psychologycal Aid juga dapat diberikan kepada responden pertama dan bantuan bencana lainnya pekerja.

\section{Pertolongan Psikologis Pertama} dirancang oleh pekerja kesehatan mental dan pekerja tanggap bencana lain yang memberikan bantuan awal kepada anak-anak yang terkena dampak, keluarga, dan orang dewasa sebagai bagian dari upaya tanggap bencana yang terorganisir. Penyediaan layanan ini dapat tertanam dalam berbagai unit respon, termasuk tim responden pertama, perintah insidensistem, primer dan perawatan kesehatan darurat, tim sekolah respon krisis, organisasi keagamaan, Komunitas Tim Tanggap Darurat (CERT), Medis Cadangan Corps, Warga Corps, dan organisasi bantuan bencana lainnya.
Pertolongan Psikologis Pertama didukung oleh bencana ahli kesehatan mental sebagai intervensi akut pilihan ketika menanggapi kebutuhan psikososial anak-anak, orang dewasa dan keluarga yang terkena bencana dan terorisme. Pada saat penulisan ini, model ini memerlukan dukungan empiris yang sistematis; namun karena banyak komponen telah dibimbing oleh penelitian, ada konsensus diantara para ahli bahwa komponen ini memberikan cara yang efektif untuk membantu korban mengelola pasca bencana, dan untuk mengidentifikasi mereka yang mungkin membutuhkan layanan tambahan (National Child Traumatic Stress Network National Center for PTSD, 2000).

\section{METODE}

Pelatihan first psychologycal aid pada anak panti dilakukan dengan memberikan psikoedukasi, bimbingan konseling, sharing pengalaman, psikogame, ketrampilan coping stress dengan menggunakan pendekatan interaktif, mengajak untuk dapat berperan aktif bukan hanya sebagai pendengar tetapi juga aktif untuk bertanya, serta berperan dalam sharing dan praktek terkait ketrampilan first psychological aid sehingga mampu mendapatkan manfaat yang optimal dari pelatihan ini. 
Tabel 1. Jadwal agenda perlakuan

\begin{tabular}{|c|c|c|c|}
\hline Sesi & Waktu & Agenda Kegiatan & Manfaat \\
\hline $\begin{array}{l}\text { Pre } \\
\text { Test }\end{array}$ & Minggu I & Screning peserta & $\begin{array}{l}\text { Mengetahui tingkat copping stres dan regulasi } \\
\text { emosi anak panti sebelum mengikuti } F P A\end{array}$ \\
\hline I & Minggu II & $\begin{array}{l}\text { Pengantar } \\
\text { Membangun } \\
\text { hubungan terapi }\end{array}$ & $\begin{array}{l}\text { Membangun hubungan terapi (yaitu, } \\
\text { empati,kolaborasi,keselarasan,penerimaan tanpa } \\
\text { syarat pasien sebagai orang) Memperkenalkan } \\
\text { diri kepada peserta terapi. Mempersiapkan } \\
\text { peserta untuk mengikuti proses terapi. Membuat } \\
\text { norma-norma yang harus disepakati bersama. } \\
\text { Menumbuhkan suasana rileks dan mengurangi } \\
\text { ketegangan bagi para peserta. Menumbuhkan } \\
\text { motivasi peserta untuk dapat mengikuti } \\
\text { keseluruhan proses terapi agar dapat } \\
\text { memperoleh manfaat dari proses terapi secara } \\
\text { maksimal }\end{array}$ \\
\hline \multirow[t]{2}{*}{ II } & Minggu III & $\begin{array}{l}\text { Ceramah, diskusi, } \\
\text { shsring }\end{array}$ & $\begin{array}{l}\text { Peserta mampu mengerti dan memahami stress, } \\
\text { coping stres. } \\
\text { Peserta mampu mengerti dan memahami stres, } \\
\text { coping stres. } \\
\text { Peserta mampu introspeksi diri sendiri terkait } \\
\text { kondisi dan kemampuannya dalam stres, coping } \\
\text { stres. }\end{array}$ \\
\hline & & $\begin{array}{l}\text { Menayangkan video } \\
\text { clip, kemudian } \\
\text { peserta diminta } \\
\text { untuk } \\
\text { mendiskripsikan apa } \\
\text { yang muncul setelah }\end{array}$ & $\begin{array}{l}\text { Peserta lebih mampu mengerti, memahami } \\
\text { menganalisa karakter, mamahami karakter, cara } \\
\text { berfikir, sudut pandang orang lain dalam video. } \\
\text { Peserta mengobservasi tayangan video clip. } \\
\text { Mampu menginternalisasi, memahami suasana } \\
\text { apa yang terjadi video clip. }\end{array}$ \\
\hline
\end{tabular}




\begin{tabular}{|c|c|c|c|}
\hline & & $\begin{array}{l}\text { melihat video clip } \\
\text { tersebut. }\end{array}$ & $\begin{array}{l}\text { Mampu mendiskripsikan apa yang dirasakan } \\
\text { dalam video clip. }\end{array}$ \\
\hline \multirow{2}{*}{\multicolumn{2}{|c|}{ IV }} & $\begin{array}{l}\text { Ceramah, } \\
\text { shsring }\end{array}$ & $\begin{array}{l}\text { Peserta mampu mengerti dan memahami } \\
\text { regulasi emosi. } \\
\text { Peserta mampu mengerti dan memahami } \\
\text { regulasi emosi. } \\
\text { Peserta mampu introspeksi diri sendiri terkait } \\
\text { kondisi dan kemampuannya dalam regulasi } \\
\text { emosi. }\end{array}$ \\
\hline & & $\begin{array}{l}\text { Menayangkan video } \\
\text { clip, kemudian } \\
\text { peserta diminta } \\
\text { untuk } \\
\text { mendiskripsikan apa } \\
\text { yang muncul setelah } \\
\text { melihat video clip } \\
\text { tersebut. }\end{array}$ & $\begin{array}{l}\text { Peserta lebih mampu mengerti, memahami } \\
\text { menganalisa karakter, mamahami karakter, cara } \\
\text { berfikir, sudut pandang orang lain dalam video. } \\
\text { Peserta mengobservasi tayangan video clip. } \\
\text { Mampu menginternalisasi, memahami suasana } \\
\text { apa yang terjadi video clip. } \\
\text { Mampu mendiskripsikan apa yang dirasakan } \\
\text { dalam video clip. }\end{array}$ \\
\hline
\end{tabular}

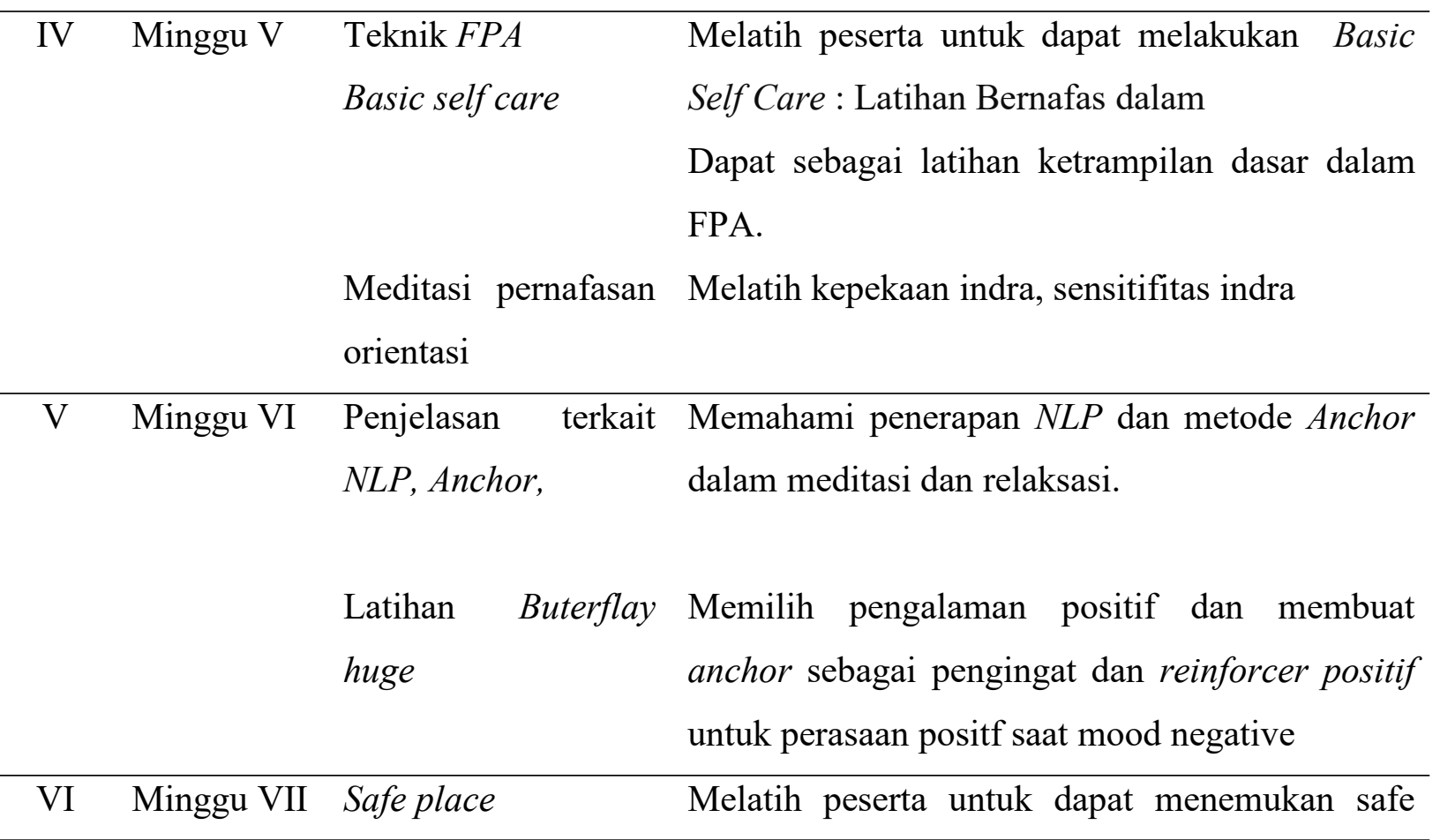




\begin{tabular}{|c|c|c|c|}
\hline & & & $\begin{array}{l}\text { place, merasakan safe place tersebut dan } \\
\text { membuat anchor, dan jika kondisi mood tidak } \\
\text { nyaman dapat menemukan sensasi safe place } \\
\text { dengan melakukan buterflay huge hingga } \\
\text { muncul perasaan positif. }\end{array}$ \\
\hline & & $\begin{array}{l}\text { Menggambarkan } \\
\text { safe place }\end{array}$ & $\begin{array}{l}\text { Peserta mampu memvisualisasikan safe place, } \\
\text { sehingga ketika melihatnya muncul mood } \\
\text { positif. }\end{array}$ \\
\hline VII & $\begin{array}{l}\text { Minggu } \\
\text { VIII }\end{array}$ & Countener & $\begin{array}{l}\text { Melatih peserta untuk mampu meredam emosi, } \\
\text { salah satunya dengan menyimpan masalah untuk } \\
\text { sementara, hingga peserta mampu lebih produtif } \\
\text { saat melakukan pekerjaannya. }\end{array}$ \\
\hline VIII & $\begin{array}{l}\text { Minggu } \\
\text { VIII }\end{array}$ & Pain Managemen & $\begin{array}{l}\text { Melatih peserta untuk mampu menanggulangi } \\
\text { rasa sakit yang dialami dengan meditasi }\end{array}$ \\
\hline Post & Minggu & Evaluasi & Evaluasi dari pelaksanaan Pelatihan $F P A$ \\
\hline Test & VIII & $\begin{array}{l}\text { Pengerjaan soal post } \\
\text { test }\end{array}$ & $\begin{array}{l}\text { Mengetahui skor coping stress dan regulasi } \\
\text { emosi setelah mengikuti Pelatihan } F P A\end{array}$ \\
\hline
\end{tabular}

\section{HASIL}

Tabel 2. Uji beda Paired Samples Statistics

\begin{tabular}{llllcc}
\hline & & & & & \multicolumn{2}{c}{ Std. Error } \\
\cline { 5 - 6 } & & Mean & $N$ & Std. Deviation & Mean \\
\hline Pair & BC Pre & 77.38 & 21 & 8.108 & 1.769 \\
\hline 1 & BC & 83.10 & 21 & 5.612 & 1.225 \\
Post & & & & & \\
\hline Pair & ED Pre & 91.29 & 21 & 9.773 & 2.133 \\
\hline 2 & ED Post & 106.52 & 21 & 14.320 & 3.125 \\
\hline
\end{tabular}


Paired Samples Correlations

\begin{tabular}{ccccccc}
\hline & & & $N$ & Correlation & Sig. \\
\hline Pair 1 & $B C$ & Pre \& BC & Post & 21 & .018 & .939 \\
\hline Pair 2 & $E D$ & Pre \& ED & Post & 21 & .071 & .760 \\
\hline
\end{tabular}

Paired Samples Test

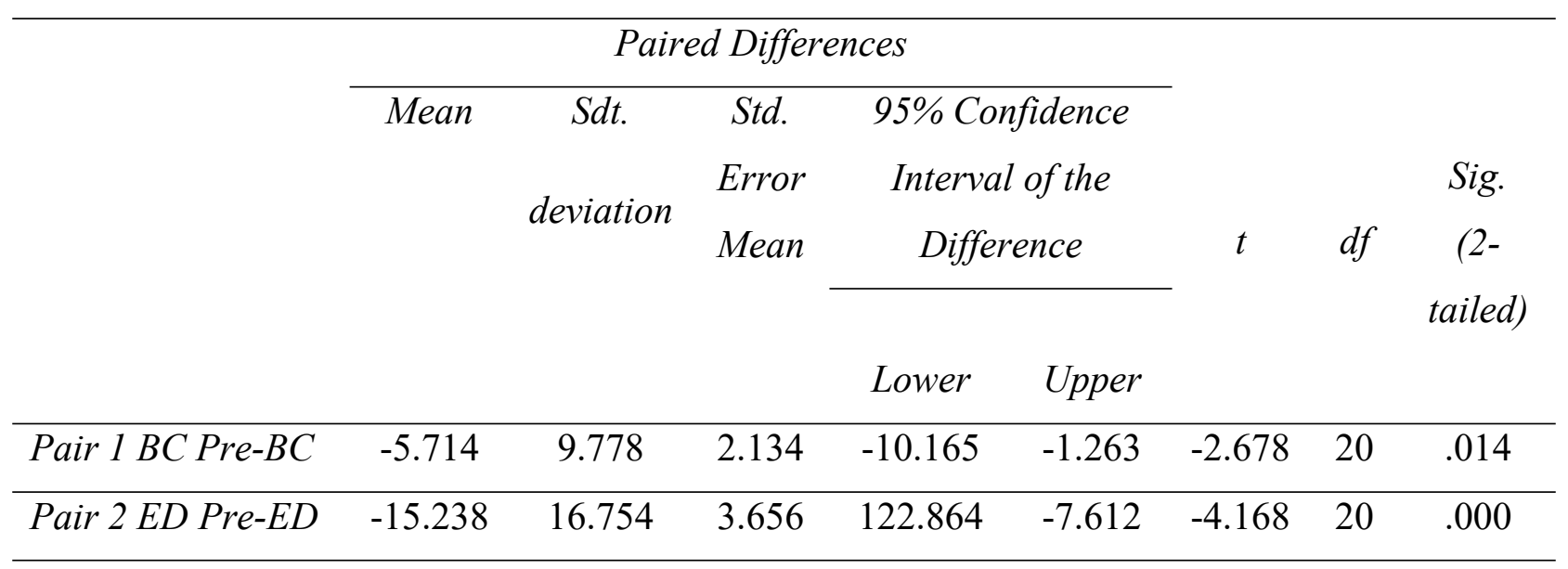

Berdasarkan hasil analisis dengan menggunakan uji $t$ diperoleh hasil $t$ : - 2,678 dengan nilai $\mathrm{p}: 0,014(\mathrm{p}<0,05)$, hal ini menunjukkan ada perbedaan yang signifikan antara coping stress sebelum pelatihan dengan coping stress setelah pelatihan. Pada regulasi emosi, nilai t: $-4,168$ dengan nilai p: 0,000 $(\mathrm{p}<0,01)$, yang juga menujukkan adanya perbedaan kemampuan regulasi emosi sebelum dan sesudah pelatihan.

\section{PEMBAHASAN}

Berdasarkan hasil observasi dan wawancara juga menunjukkan hal yang serupa. Nampak terjadi perkembangan yang positif, terlihat dari interaksi antara psikolog dengan peserta terapi. Pada pertemuan awal, memang psikolog mengalami kesulitan dalam membangun komunikasi, namun seiring dengan waktu berjalan, secara perlahan anakanak panti mulai terbuka dan dapat berkomunikasi dengan baik.

Sharing yang dilakukan oleh tim mendapatkan beberapa data yang cukup penting. Berbagai permasalahan yang dialami oleh anak-anak, dan sejauhmana mereka mampu mengatasi permasalahan tersebut. Hal yang paling mendasar adalah ketidakmampuan anak-anak panti asuhan dalam mengenali dan memahami penyebab 
munculnya stress pada diri mereka. Hal ini menjadi penting, karena perubahan kondisi fisik dimulai dari perubahan kondisi emosi. Walgito (1994) menyatakan bahwa Jika seseorang mengalami ketakutan mukanya menjadi pucat, jantungnya berdebar-debar, jadi adanya perubahan-perubahan kejasmanian sebagai rangkaian dari emosi yang dialami oleh individu yang bersangkutan.

Menurut Stanly Hall masa remaja dikenal sebagai masa strome and stress, dimana remaja banyak sekali mengalami masalah, serta membutuhkan banyak coping baik emosi maupun problem focus coping (Davinson, 2006). Hal ini dapat terjadi karena pada masa remaja setiap individu mengalami perubahan hormonal yang sangat pesat sekali. Proses perubahan hormone yang terjadi didalam tubuh mengakibatkan terjadinya perubahan respon dari inividu yang bersangkutan. Perubahan cukup besar terjadi baik terkait emosi, maupun perilaku (Sarwono, 2006). Hal tersebut menunjukkan sangat besar peran individu lain mendampingi dalam proses tumbuh kembang remaja (Gunarsa, 2008). Remaja masih membutuhkan peran pendampingan, pengawasan dari figure yang lebih dewasa dalam penyelesaian masalah maupun emosi (Hurlock,(2008);Santrock,(2003); Gunarso,(2008); Sarwono,(2006)).
Namun disisi lain, remaja yang tinggal dipanti asuhan tidak mendapatkan hal tersebut. Remaja yang tinggal di pantiasuhan merupakan anak yatim, atau piatu, yatim piatu, dan ada juga yang masih memiliki orang tua, namun terpaksa dititipkan dipati asuhan karena kondisi ekonomi keluarga yang sangat kekurangan. Orang tua menitipkan ke pantiasuhan denga harapan dapat mendapatkan kebutuhan lebih layak, termasuk pendidikan. Hal tersebut menjadi beban tersendiri bagi remaja pantiasuhan. Adanya tuntutan pengelolaan masalah dan emosi secara mandiri. Apabila mereka sejak kecil masuk pantiasuhan, artinya mereka sudah mendapatkan beban tersebut lebih lama. Freud menguangkapkan jika hal tersebut mengakibatkan penumpukan beban psikologis yang besar karena anak atau remaja cenderung melakukan represi yang memunculkan penyakit psikis misalnya kemampuan kontrol emosi yang kurang matang, penyelesaian masalah yang kurang tepat, sensitivitas berlebih (Davinson, 2006). Hal ini juga sangat terlihat pada para remaja dipanti asuhan. Pada saat awal pelaksaan pelatian hingga akhir pelatihan sering memunculkan perilaku yang mencerminkan control emosi yang kurang, maupun penyelesaian masalah yang kurang bagus, misalnya dengan mengutarakan kata kata 
kasar dengan teman yang tidak sengaja menyindir, dan terlihat lagi ketika saat pelatihan masuk sesi darwing therapy, saat menanyakan makna apa yang terkandung dalam gambar, terdapat beberapa peserta yang menjelaskan dengan lantang dan marah, kemudian ada juga yang menangis dan hanya diam serta setelah mengatakan beberapa kalimat.

Hal lain yang menjadi masalah klasik adalah tindak bullying yang dilakukan oleh teman sekolah mereka karena mengetahui jika mereka seorang anak pantiasuhan. Anggapan yang masih termapiang adalah anak panti anak yang kekuarangn, miskin, rendah. Hal tersebut menjadikan mereka sering mendapatkan perlakuan tidak adil. Mereka sering mengalami diskriminasi oleh teman temannya. Mereka merasakan lelah mental karena hal tersebut sering kali mengalaminya. Dampak bullying sangat berbahaya dan dapat menjadikan trauma pada korban, harga diri korban, kepercayaan diri korban akan rendah (Peterson, C., \& Park, N. (2011); Coloroso, (2007)).

Masa remaja adalah masa dengan kemampuan bersosialisasi yang kuat terhadap temen dekat dan teman sebaya. Namun hal berbeda terjadi pada mereka. Mereka sangat membutuhkan dukungan sosial terkait kondiosi yang dialaminya. Dukungan Sosial adalah informasi atau umpan balik dari orang lain yang menunjukkan bahwa seseorang dicintai dan diperhatikan, dihargai, dan dihormati, dan dilibatkan dalam jaringan komunikasi dan kewajiban yang timbal balik (King, 2012). Selanjutnya, dukungan sosial menurut Cohen \& Syme (2005) adalah sumber-sumber yang disediakan orang lain terhadap individu yang dapat mempengaruhi kesejahteraan individu bersangkutan. Lebih lanjut dukungan sosial menurut House \& Khan (1995) adalah tindakan yang bersifat membantu yang melibatkan emosi, pemberian informasi, bantuan istrumen, dan penilaian positif pada individu dalam menghadapi permasalahannya. Dukungan sosial memiliki tiga jenis manfaat, yaitu bantuan yang nyata, informasi, dan dukungan emosional menurut Taylor (2009). Hal tersebut juga merujuk pada pendapat Hurlock (2008), jika remaja membutuhkan bimbingan dan pendampingan dari figure yang lebih dewasa.

Kesadaran dan pemahaman akan kondisi emosi yang berpengaruh terhadap kondisi fisik seseorang tentunya harus dibarengi dengan kemampuan orang tersebut dalam meregulasi emosinya. Rothbart dan Sheese (2007) menyatakan bahwa regulasi emosi merupakan perubahan dari reaksi emosi, 
yang meliputi inhibisi, aktivasi, atau perubahan bertingkat. Regulasi emosi meliputi strategi yang diterapkan melalui usaha pengendalian dan perubahan pengaruh terhadap emosi.

Pelatihan FPA menitikberatkan pada kemampuan individu dalam menggunakan berbagai teknik - teknik psikologi dalam menghadapi permasalahan untuk mengendalikan emosi dirinya. Tim pengabdian dalam pertemuan selanjutnya memberikan berbagai teknik pengendalian emosi kepada peserta terapi ataupun pelatihan. Tim memberikan lima teknik dasar pengendalian emosi. Teknik ini dapat diterapkan secara mandiri maupun peserta dapat mengajarkan teknik ini kepada orang lain.

Beberapa kendala yang ditemui saat tim berupaya membekali teknik psikologi kepada anak-anak panti asuhan, diantaranya adalah sebagian besar belum pernah menggunakan teknik yang disampaikan. Hal tersebut masih terdengar asing bagi mereka. Maka perlu waktu dan latihan berulang kali agar peserta dapat mempraktekkan teknik tersebut dengan tepat dan efektif. Pertemuan awal disajikan psikoedukasi terkait pentinganya memahami apa yang dirasakan. Setelah itu membimbing peserta untuk lebih mengenal diri mereka sendiri. Mengasah kepekaan pribadi terkait diri sendiri. Kemudian mengenali hal apa yang bisa memicu emosi dan meredam emosi. Setelah itu mulai melatih mengkontrol emosi dengan proses relaksasi.

Latihan relaksasi membutuhkan banyak sekali bimbingan (William, 1996). Namun hasilnya cukup baik bagi peserta. Mereka menyatakan dapat lebih nyaman, lebih bisa untuk menahan amarah, walaupun awalnya sulit sekali, dan cenderung tidak mempercayai jika hanya dengan berolah nafas mampu untuk meredam emosi. Relaksasi mampu memicu keluarnya hormone antri stress yaitu dopamine, endorphin, saat reles individu memproduksi ocsitisin dan serotonin. Sehingga lebih tenang dan mampu lebih baik lagi saat berfikir atau menyelesaikan masalah (Seimun, 2010). Selain itu Seimun (2010), juga mengungkapkan saat orang stress otak dipenuhi kortisol sehingga tidak bisa berfikir jernih. Hal tersebut akan memicu muncul ntindakan yang maladaptive pada seseorang, tindakan yang tidak sesuai dengan seharusnya. Maka dari itu penting sekali dilakukan pelatihan pengelolaan emosi dan coping stress. Selama proses pelatihan juga muncul kendala yaitu adanya beberapa peserta yang mengalami tantrum atau ekspresi emosi yang kurang dapat dikendalikan. Hal tersebut terjadi karena ada beberapa peserta yang 
memiliki pengalaman buruk yang menjadi trauma mabi mereka. Sehingga membutuhkan penanganan dan pendampingan khusus dari psikolog.

Peserta yang mengalami peristiwa traumatis sangat memungkinkan mengalami hal ini. Selain itu tim pengabdian telah mempersiapkan beberapa penanganan, diantaranya adalah adanya sesi konseling dan konsultasi dengan psikolog dan bila perlu psikolog memberikan terapi lain untuk menangani permasalahan yang dialami oleh peserta.

Berbagai kendala yang muncul dapat tim atasi, sehingga pelatihan dapat berjalan secara efektif. Peserta menunjukkan perkembangan positif dari waktu ke waktu selama pelatihan berlangsung. Beberapa peserta menunjukkan perbedaan yang sangat signifikan secara emosi dan perilaku. Berawal sangat sulit menjadi bermunculan peserta yang secara suka rela menunggu dan mengajak temannya mengikuti program pelatihan ini dan aktif dalam mengikuti kegiatan di setiap sesinya.

\section{KESIMPULAN DAN SARAN}

Kegiatan pelatihan ini bertujuan untuk membekali anak-anak panti asuhan dalam menghadapi permasalan mereka dan bagaimana mereka meregulasi emosi diri.
Perlu dipahami bahwa pelatihan ini sesuai dengan namanya merupakan langkah pertama dalam penanganan psikologi. Namun tidak bisa dipungkiri kebutuhan pendamping yang dapat memberikan pengaruh psikologi yang positif bagi anak-anak juga sangat diperlukan. Seseorang yang mampu berkomunikasi dan menjadi tempat berkeluh kesah serta mampu membimbing anak-anak panti asuhan menghadapi permasalahan.

Mengenali permasalahan dan memahami bagaimana hal tersebut berpengaruh bagi emosi dan fisik adalah hal yang penting bagi manusia. Hal yang sangat penting di latihkan pada anak - anak panti asuhan adalah kemampuan untuk menerima apa pun yang dialami, apapun yang ada dalam dirinya, apapun yang dimilikinya baik sisi positif amupun sisi negatif. Pada hakikatnya harus difahamkan tidak ada yang sempurna dimuka bumi ini. Ketika mereka melihat keluar, mungkin mereka merasa dirinya kecil, namun itu terjadi karena sebetulnya tidak mengetahui apa masalah orang yang ada diluar, hingga merasa mereka yang diluar itu lebih baik. Anak - anak panti hendaknya di latih agar mampu memahami dan menerima keadaan dirinya. Mengetahui kapan akan marah, apa yang membuat mereka marah, menangis,bagaiman agar dirinya tidak marah maupun menangis. Setelah itu melatih 
menerima apapun yang terjadi dan berlatih berpikir positif. Dengan begitu mereka akan lebih mudah mencari makna, mengelola emosi.

Ketrampilan ini diharapkan tidak hanya digunakan untuk diri sendiri, namun dapat disebarkan ke orang lain yang membutuhkan. Anak-anak panti asuhan yang telah mendapatkan pelatihan diharapkan dapat menerapkan teknik ini untuk dirinya sendiri, dan jika memungkinkan dapat membantu teman-temannya dengan mengajarkan teknik

\section{DAFTAR PUSTAKA}

Brymer M, Jacobs A, Layne C, Pynoos R, Ruzek J, Steinberg A, Vernberg E, Watson P., (2006).Psychological First Aid Field Operations Guide 2nd Edition (National Child Traumatic Stress Network and National Center for PTSD). National Reserch Center publisher

Campbell-Sills, L., \& Barlow, D. H. (2007). Incorporating emotion regulation into conceptualizations and treatments of anxiety and mood disorders. In J. J. Gross (Ed.), Handbook of emotion regulation (pp. 542-560). New York, NY: Guilford Press.

Carver CS, Scheier MF \& Werintraub JK. Assessing Coping Strategies:A Theoretically Based Approach. Journal of Personality and Social Psychology, 1989; 56(2) :267-283.

Cohen, S and Syme, S.I. 2005. Social Support And Health. London: Academic Press Inc. Coloroso, B. (2007). Stop Bullying. Jakarta: PT. Serambi Ilmu Semesta.

Dahlqvist V, Soderberg A \& Norberg A. Dealing with stress: Pattern of self- yang telah dipelajari. Selain itu harapan kami dibentuk kelompok kelompok kecil yang terdiri dari 5 orang tiap kelompok dari berbagai usia. Kelompok tersebut secara berkala dapat berkumpul. Sebagai sarana saling mentoring satu sama lain.

Hal lain yang dapat dilakukan adalah menjalin kerjasama dengan orang yang memiliki kompetensi seperti psikolog. Dengan adanya psikolog aka nada orang yang mampu berperan membantu dalam mengatasi masalah berat yang dialami.

comfort among healthcare students. Nurse Education Today, 208; 28(4): 476-484.

Davinson. (2006). Psikologi Abnormal. Jakarta : Rajawali Press

Davidson, R. J., Lewis, D. A., Alloy, L. B., Amaral, D. G., Bush, G., Cohen, J. D., ... Peterson, B. S. (2002). Neural and behavioral substrates of mood and mood regulation. Biological Psychiatry, 52, 478-502.

Dawson AE. Negative Coping Strategies Mediating the Relationship of Adolescent Attachment Classifications and Future Externalizing Behaviors. L. Starling Reid Undergraduate Psychology, 2009:1-42. $<$ http://minerva.acc.virginia.edu/psych ology/downloads/DMP\%20

Papers/Dawson-2009.pdf> (28 Juni 2019).

Ekman, P. (1999). Basic emotion. In T. Dalgleish \& M. Power (Eds.), Handbook of cognition and emotion (pp. 
45-60). Chichester, England: John Wiley \& Sons, Ltd.

Ekman, P. (2003). Emotions revealed: Recognizing faces and feelings to improve communication and emotional life. New York, NY: Times Books.

Folkman S. Ways of Coping Checklist (WCCL). Encyclopedia of Behavioral Medicine, 2013: 2041-2042.

Goleman, Daniel. (2002). Kecerdasan Emosional. Jakarta: PT. Gramedia Pustaka.

Gross, J., John, O.P. (2003). Individual Defferences in two Emotion Regulation Proceses for Affect, Relationship, And Well being. Journal of Personality and Social Psychology, 5 (5), 348-362

Gross, J. J. (Ed.). (2007). Handbook of emotion regulation. New York, NY: Guilford Press.

Gross. 2015. Emotion Regulation:Current Status and Future Prospects. James J. Gross Department of Psychology, Stanford University, Stanford, California. Psychological Inquiry, 26:126, 2015Copyright.Taylor \& Francis Group, LLCISSN: 1047-840X print / 1532-7965 online DOI: 10.1080/1047840X.2014.940781

Gross, J. J., \& Levenson, R. W. (1993). Emotional suppression: Physiology, self-report, and expressive behavior. Journal of Personality and Social Psychology, 64, 970-986.

Gross, J. J., \& Levenson, R. W. (1997). Hiding feelings: The acute effects of inhibiting positive and negative emotions. Journal of Abnormal Psychology, 106, 95-103.

Gross, J. J., \& Munoz, R. F. (1995). Emotion regulation and mental health. Clinical Psychology: Science and Practice, 2, 151-164.

Gross, J. J., \& Thompson, R. A. (2007). Emotion regulation: Conceptual foundations. In J. J. Gross (Ed.),
Handbook of emotion regulation (pp. 324). New York, NY: Guilford Press.

Gunarsa, Singgih D. 2008. Psikologi Anak: Psikologi Perkembangan Anak dan Remaja. Jakarta: PT BPK Gunung Mulia.

Holland K. A study to identify Stressors perceived by Health Science Lecturing staff within a school at a South African University.2001:1-107. $<$ http://hdl.handle.net/10413/5683> (Accessed 10 Juni 2019)

House, J. \& Kahn, R.L. 1995. Measures and concept of social support. London: Academic Press Inc.

Hurlock, E.B (2008). Psikologi Perkembangan: Suatu Pendekatan Sepanjang Rentang

Kehidupan. Jakarta: Erlangga.

Kasayira JM, Chipandambira KS \& Hungwe, C. Stressors and coping strategies of state university students in a developing country. Journal of Psychology in Africa, 2007;17 (1-2): 45-50.

Kausar R. Perceived Stress, Academic Workload and Use of Coping Strategies by University Students. Journal of Behavioural Sciences, 2010; 20(1): 31-45.

Kawuryan, F., Astuti, D. (2015). Identifikasi Stresor Mahasiswa. Perpustakaan Fakultas Psikologi UMK.

King, A. Laura. (2012). Psikologi Umum (Sebuah Pandangan Apresiatif). Jakarta: Salemba

\section{Humanika}

Kumar S. \& Jejurkar K. Study of stress level in occupational therapy students during their academic curriculum. The Indian Journal of Occupational Therapy, 2005; 37(1): 11-14.

Montero-Marín J, García-Campayo J, Mosquera D, López Y (2009) A new definition of burnout syndrome based on Farbers's proposal. J Occup Med Toxicol 4: 31. 
Monks, F. J. (1990). Psikologi Perkembangan. Yogyakarta: Gajah Mada University Press

Mosley TH, Perrin SG, Neral SM, Dubbert PM, Grothues CA \& Pinto BM. Stress, Coping and Well-Being among Thirdyear Medical Students. Academic Medicine, 1994; 69(9): 765-767.

Myers, D. G. (2012). Social Psychology. Jakarta: Salemba Humanika.

(2012). Social Psychology

Eleventh Edition. New York: The McGraw Hill

Companies, Inc.

Lazarus, R.S. dan Folkman, S. 1986. Stress, Appraisal, and Coping. New York : Springer.

Ochsner, K. N. \& Gross, J. J. (2005). The cognitive control of emotion. Trends in Cognitive Sciences, 9, 242-249.

Peterson, C., \& Park, N. (2011). Character strengths and virtues: Their role in well-being. In S. Donaldson, M. Csikszentmihalyi, \& J. Nakamura (Eds.), Applied positive psychology: Improving everyday life, health, schools, work, and society. New York: Routledge.

RaReissner V, Baune B, Kokkevi A, Shifano F, Room R, et al. (2010) Burnout, coping and job satisfaction in service staff treating opioid addicts-from Athens to Zurich. Stress Health 26: 149-159.

Robotham D. Stress among higher education students: towards a research agenda. Higher Education, 2008; 56(6): 735-746.

Rothbart., Sheese. (2007). Developing Mecanisms of Self Regulation in Early Life. Journal. PMC3164871.

Sarafino, E. P., Timothy W. Smith. 2011. Health Psychology: Biopsychosocial Interactions, 7th edition. Amerika Serikat: John Wiley \& Sons, Inc.
Santrock (2003) John W. Adolescence. Perkembangan Remaja. Edisi Keenam. Jakarta: Erlangga.

Sarid A, Anson O, Yaari A \& Margalith M. Academic Stress, Immunological Reaction and Academic Performance among students of Nursing and Physiotherapy. Research in Nursing and Health, 2004; 27(5): 370-377.

Sarwono, S.W. (2005). Psikologi Sosial Psikologi Kelompok dan Psikologi Terapan. Jakarta: Balai Pustaka.

Sarwono, S.W. (2006). Psikologi Remaja. Jakarta: Raja Grafindo Persada.

Shaheen F \& Alam S. Psychological Distress and its Relational to Attributional Styles and Coping Strategies Among Adolescents. Journal of the Indian Academy of Applied Psychology, 2010; 36(2): 231-238.

Shankar PR, Binu VS, Mukhopadhyay C, Ray, B. \& Menezes RG. Psychological morbidity, sources of stress and coping strategies among undergraduate medical students of Nepal. BMC Medical Education, 2007; 7(1): 1-8.

Taylor, S. E, dkk. (2009). Psikologi Sosial. Edisi kedua belas. Jakarta: Kencana Prenada Media Group.

Thompson. 2015. Assessing Cognitive and Affective Empathy Through the Interpersonal Reactivity Index: An Argument Against a Two-Factor Model $1-9$. Reprints and permissions: sagepub.com. Journal Permissions. nav DOI: $\quad 10.1177 / 1073191115599055$. asm.sagepub.com

Walgito,B. (1994). Pengantar Psikologi Umum. Jogjakarta : Andi Offset.

Wentzel, K. R. (1998). Social relationships and motivation in middle school: the role of parents, teachers, and peers. Journal of Educational Psychology, 90(2), hlm. 202-209.

Yusuf, S. (2009). Psikologi Perkembangan Anak dan Remaja. Bandung : Rosda Karya 
